\title{
Obituaries
}

\section{ANGELA FLETCHER}

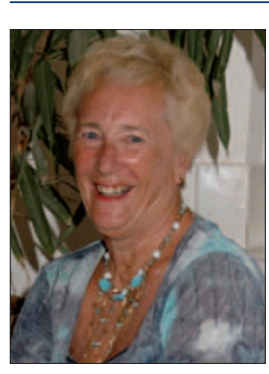

Angela Fletcher was brought up in Essex but chose Liverpool University to study dentistry where she qualified in 1964. From 1966 she worked in the

Prosthetics Department at University College Hospital Dental School where she finally became Head of Department before the closure of the school in 1990. Angela was a most respected and effective teacher and very much respected by her students, both undergraduate and postgraduate, to whom she was fiercely loyal. Equally to her patients she was a kind and most skilful prosthodontist. Slightly intimidating due to her forthright manner, she showed no hesitation in making her voice heard in matters she considered important. During these years, the third BDS examination in prosthetic dentistry included dental materials and as UCH was without a dedicated teacher in materials science, Angela obtained the diploma of member of the Institute of Materials and accepted the role of teaching the materials course. Profound respect for her was shown when she was elected president of the British Society for the Study of Prosthetic Dentistry in 1991; until this present year the only woman president in 60 years of the society.

Following the closure of UCH Dental School, Angela took a part-time position in the Prosthetics Department at Guy's Hospital where her teaching in prosthetics was as equally appreciated as it had been at UCH. Angela finally retired in 2005.
In her life beyond dentistry Angela was a keen golfer, serving as Ladies Captain of the Wanstead Golf Club.

Angela was married to Cyril who, although not a dentist, was frequently seen at her side at many dental conferences. Cyril died in 2008 and Angela reconnected with David whom she had known since she was younger and they were married in Australia in 2010. At the time of their marriage Angela had no hint of the illness which within a few months would bring her back to England and after even fewer months she died in January 2011. The roll of former senior colleagues at her funeral was more than enough evidence of the great respect in which she was held. We extend to David and all her family our sincere condolences.

Peter R. Likeman

\section{JOHN CHARLES CASTON GILL}

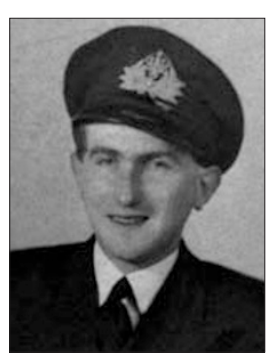

Known to friends and colleagues as 'Peter', J. Caston Gill LDS was born on 5 May 1921 at Wednesbury. Educated at Queen Mary's Grammar School, Walsall, he entered the University of Birmingham Dental School in 1939. Qualifying in 1944 he immediately entered the Royal Navy; at first he was Portsmouth based and was then transferred to Plymouth where he remained until he was demobilised in 1947. It was while he was in Plymouth that Peter met Barbara whom he later married.

On returning to the Midlands, Peter went on a refresher course at the Birmingham Dental School and undertook
Obituaries should be submitted by email to Laura Pacey at I.pacey@nature.com.

All submitted obituaries should be 350 words maximum in length (apart from obituaries for past presidents of the BDA where the length should be $700-800$ words).

Content of the obituary is down to the individual author, and the approval of the family should be given for the obituary prior to submission to the $B D J$. several assistantships in practices in the Birmingham area.

However, the lure of the beautiful city of Plymouth was too much for him and he decided to return. He was unable to obtain employment in the Plymouth area and decided to embark on a practice of his own. This was very difficult in 1947. He was forced to return to Birmingham to work part time and to return to Plymouth for the remainder of the week in a two-seater Morris Eight. He remained in general practice in Plymouth until his retirement in 1990.

In 1957, Peter took on the post of Resident Dental Surgeon at the Department of Oral Surgery, Greenbank Hospital. For Peter this was a very happy time in his career.

He served on many committees, was a very active member of the Plymouth Section of the BDA and was on the Western Counties Branch Council for a long time.

On his retirement, Peter and Barbara decided to move closer to their younger daughter Anna who lived in North Wales on the Isle of Anglesey. This proved to be fortunate as Peter began to suffer from macular disease of the 'wet' variety and although it was treated he lost a lot of his vision. This deprived him of two great loves, namely high performance motor cars and photography. He suffered a further devastating blow later when he sadly lost his beloved wife, Barbara to cancer.

Peter died on 12 May 2012 and leaves two daughters and five grandchildren.

JCCG 